\title{
Spatiotemporal variations of Chinese lakes and their driving mechanisms since the Last Glacial Maximum: A review and synthesis of lacustrine sediment archives
}

\author{
SHEN Ji \\ State Key Laboratory of Lake Science and Environment, Nanjing Institute of Geography \& Limnology, Chinese Academy of Sciences, \\ Nanjing 210008, China
}

Received May 24, 2012; accepted September 7, 2012; published online November 22, 2012

\begin{abstract}
In this article, the author provides the first synthesis and classification of available environment-indicating proxies for lacustrine sediment. A review of spatio-temporal variations in lakes from the Tibetan Plateau, the dry areas of Northwestern China, the Yunnan-Guizhou Plateau and the plains of Eastern China since the LGM is then provided. The driving mechanism for variations in lake processes and characteristics is also discussed based on various temporal scales. The author then proposes that future investigations be conducted to: (1) strengthen the study of theoretics and interpretation of environment-indicating proxies, (2) enhance the study of high-resolution time series and spatial variability of lake environment evolution, (3) provide more attention on the influence of human activities on lake environments, and (4) boost construction of the Quaternary lake database of China.
\end{abstract}

spatiotemporal variation, Chinese lakes, driving mechanism, LGM

Citation: Shen J. Spatiotemporal variations of Chinese lakes and their driving mechanisms since the Last Glacial Maximum: A review and synthesis of lacustrine sediment archives. Chin Sci Bull, 2013, 58: 17-31, doi: 10.1007/s11434-012-5510-7

Lakes are normally formed under various geological and geographical backgrounds. As a component of the terrestrial hydrosphere, lakes have close relationships with the atmosphere, biosphere and lithosphere, and serve as the connection between these systems. Once a lake is formed, it is influenced by a series of tectonic, climatic and anthropogenic factors. As a result, lacustrine evolutional processes usually involve geological, physical, chemical and biological processes and the interactions between them, and these processes are all documented by lacustrine sediment archives. Because lakes are widely distributed worldwide and normally undergo a long history of evolution, lacustrine sediment generally possesses a continuous record with highresolutions that provides abundant information regarding regional environmental and climatic variations that can be used in global change studies. Lacustrine sediment also contains information pertaining to human activities, since

email: jishen@niglas.ac.cn people tend to settle around lakes owing to the resources they provide.

\section{Synthesis and classification of proxies in lacus- trine sediment describing environmental condi- tions}

Lakes generally have an independent watershed that serves as a source of water, sediment, biomass and chemicals, while the lake serves as a sink for all of these materials. Accordingly, lacustrine sediment can record all information regarding the source-sink interactions and mass balances including water balances (watershed rainfall and lake level stands), sediment balances (watershed erosion intensity and lake sedimentation rate), biological balances (watershed vegetation and lake biomass) and chemical balances (watershed soluble materials and lake water ion concentrations) [1]. 
The formation of lakes generally has no zonality; therefore, lakes are widely distributed around the world, being present in tropic zones, temperate zones and frigid zones, as well as humid and arid regions and at altitudes ranging from $5000 \mathrm{~m}$ above sea level (a.s.l.) (such as lakes on the Tibetan Plateau) to $-155 \mathrm{~m}$ a.s.l. (such as Lake Aiding) [2]. Nevertheless, once a lake is formed, its physical, chemical and biological processes differentiate according to the zone it is located in, and they normally possess notable regional characteristics. Therefore, to understand the relationship between zonality and lake evolution, it is essential to select suitable environment-indicating proxies; however, the interpretation of such proxies is often specific and not straightforward. To clarify the interpretation of physical, chemical and biological proxies, case studies for specific lakes must be conducted to investigate the modern processes of their watershed-lake system. Only with suitable proxies and case-specific interpretation can the regional environmental evolutions be correctly characterized. For example, lakes on the Tibetan Plateau are generally characterized by closed or semi-closed lake basins with saline or brackish waters; accordingly, the water balance is usually controlled by the precipitation/evaporation ratios, which also influence the evolution of hydrophyte communities. Therefore, for these lakes, suitable proxies are chemical and biological factors that can indicate changes in the salinity of the water they contain. Conversely, lakes in Eastern China generally have outward flows, and their lake-catchment systems are usually characterized by high biomass productivity. Therefore, suitable proxies for these lakes are biochemical factors that can indicate the biomass productivity of the lakecatchment system and cycling of the nutrient elements. Lakes in the Yunnan-Guizhou Plateau are normally characterized by lake-catchment systems with great biodiversity and obvious vertical (altitudinal) biozonality; thus, the suitable proxies should be biochemical factors that can indicate evolutions of watershed vegetation and lake hydroenvironment.

Lacustrine sediment is generally derived from allochthonous and authigenic sources. The former is from materials produced by catchment erosion, while the latter is from lake water precipitation due to various biochemical processes. The catchment erosion rate is related to the geology of the watershed and lake water deposit is related to the inner-lake biological and hydrochemical factors. Both of these sources have a close relationship with climatic changes. Hence, besides abrupt tectonic movements and human activities, climate is the only key factor that influences lacustrine sediment formations. Therefore, studying a certain layer of the sedimentary core can provide information regarding the climatic and environmental conditions for a certain period. Moreover, investigating the entire section of the sedimentary core can enable deduction of climatic and environmental changes over the time during which the sedimentary core was formed.
Lacustrine sediment proxies can generally be classified into three categories: (1) proxies indicating terrestrial (lake catchment) information such as pollen, phytolith, charcoal, grain size, susceptibility, etc.; (2) proxies indicating lake water environmental conditions including micro-fossils (diatoms, ostracods, chironomids, cladocera, macroplantfossils, etc.), pigment, authigenic carbonate and stable carbon and oxygen isotopes of the authigenic carbonate, elemental ratio and isotopes of biological shells, etc.; and (3) proxies indicating multi-source information pertaining to the lake-catchment system including total organic carbon (TOC), total nitrogen (TN), organic carbon isotopes, etc. [1]. Nevertheless, the classification of the proxies is not absolute, because proxy-indicating catchment information can also incorporate information pertaining to inner-lake alterations such as diagenesis. Accordingly, interpretation of proxies is often complicated.

\section{Spatiotemporal variations of Chinese lakes since the Last Glacial Maximum (LGM)}

From west to east, Chinese topography is characterized by the so-called "three-step ladders", which were formed by tectogenesis. The first-step ladder is the notably uplifted Tibetan Plateau, which is circled by higher mountains containing deep canyons on the outer mountainside. The inner plateau topography consists of mountains, valleys and basins, with lakes along fracture zones. These lakes consist of saline or brine with closed or semi-closed basins and freshwater lakes with intermountain basins produced by glacier erosion or river-headward erosion. The Tibetan Plateau is very lake-concentrated, with a total lake surface area that accounts for $49.5 \%$ of that of China. Most lakes now have deep water and long histories. The Hengduan Mountains are the transitional zone of the first- and second-step ladders, and are characterized by high mountains and deep canyons with diverse elevations. Lakes of this area are often situated in steep and deep depression basins, and some are dammed lakes caused by landslides and/or debris flows. The second-step ladder is characterized by plateaus and basins caused by differential elevations of land masses, which allows for tectonically-derived depression lakes. When compared with the first-step ladder, the second-step ladder is characterized by tectonic movements with lower intensities and amplitudes. As a result the lakes on the second-step ladder usually have continuously sinking lake basins, such as Lake Dianchi, Erhai, Lugu on the Yunnan-Guizhou Plateau and Lake Daihai and Huangqihai on the Mongolia Plateau. The third-step ladder consists of the extensive plains in Eastern China and is characterized by an overall sinking topography. Lakes on this ladder are often formed by river valley migrations, such as lakes of the brooky regions in the middle and lower reaches of the Yangtze River. These lakes have shallow waters, short histories and evident disturbance 
by human activities. In this paper, the spatio-temporal variations in Chinese lakes since the last deglaciation are reviewed.

\subsection{Alpine lakes in the frigid Tibetan Plateau}

According to the radiocarbon chronology of lacustrine terraces, the late interstadial of the last glacial period (40-20 $\mathrm{ka} \mathrm{BP}$, corresponding to the late marine isotope stage 3 (MIS 3a)) is when expanding lakes developed on the Tibetan Plateau, the so-called "great lake period" [3-5]. Most of these lakes are freshwater lakes [6], such as Lake Kushuihai, Tianshuihai, and Aksai Chin, which are located south of the western Kunlun Mountains. However, these characterizations have recently been challenged by data obtained from optically stimulated luminescence (OSL) and uranium series dating data, which are in obvious contrast with the above radiocarbon data $[7,8]$. For example, sediment from the same lacustrine facies in the Tengger Desert (to the northeast of the Tibetan Plateau) date back to 25-40 ka BP $[9,10]$ according to radiocarbon dating, but OSL dating indicated that they were from 70-130 ka (MIS 5) [8]. A similar scenario was also indicated by other published data [11-13], which suggests that the disagreement between the two dating methods might have been caused by the weakness of radiocarbon dating for samples older than $35 \mathrm{ka}$ BP. However, it is difficult to determine if this discrepancy is actually caused by the different dating methods. Therefore, the exact presence of the last great lake period cannot be ascertained and requires additional study.

For the period of 20-15 ka BP, lake deposits during the former interstadial ceased due to drying up of most lakes on the northeastern Tibetan Plateau. For example, the sediment of Lake Qarhan and Dachaidan during this period is characterized by originally-formed halite interbedded by silty clayish layers of gypsum, indicating dry and cold climates.

For the late glacial period (15-12 ka BP), an ameliorated climate with enhanced humidity due to increased rainfall or glacial-melt water is indicated by elevated lake levels for lakes on the Tibetan Plateau, especially for those in the middle and western Kunlun Mountains. This period was subsequently followed by a climate reversal (11.5-10 ka BP) coinciding with the Younger Dryas (YD) event, as evidenced by the lowered water stands for many lakes on the Tibetan Plateau such as Lake Seling [14] and Songxico [15-17].

The highest stands of most lakes in the Tibetan Plateau occurred during the early Holocene (11-9 ka BP). For example, most lakes in the eastern and southern parts of the Plateau have exterior drainage during this stage. In addition, a short dry period following $9 \mathrm{ka}$ BP is indicated by withdrawal of most lakes on the Plateau. For mid-Holocene, most lakes of the Plateau were characterized by elevated lake levels, expanded lake surfaces and decreased water salinities as a result of enhanced intensities of summer monsoon. Nevertheless, the lake stands were still lower than those of the early Holocene. For many lakes (Lake Peikuco, Chenco, Nariyongco, Zharinanmuco) on the south central Tibetan Plateau, spacious terraces (the third lacustrine terrace) developed along the lake banks, which date back to 7.5-3 ka BP. The lacustrine sediment is relatively fine when compared with that of the early Holocene, and many lakes on the southern Tibetan Plateau are exorheic, with much lower total dissolved solid (TDS) waters when compared to today. For example, the sediment of Lake Namco contained freshwater snail-shells in the mid-Holocene, but the TDS is currently $15 \mathrm{~g} / \mathrm{L}$. A relatively warmer climate is evidenced by high water stands, decreased water salinities and flourished vegetation for Lake Seling and Zhabuye Chaka. However, climate for the northern Tibetan Plateau appears to have led to dry conditions, as evidenced by the semiclosed hydrological conditions, lowered water stands and increased water salinities for some lakes in this region, with no discharges of glacial-melting waters. For instance, the diatom assemblages of Lake Sipanguer are characterized by relative increases of benthic and epilithic diatoms, while those of and Zhacang Chaka are characterized by deposited mirabilite and gypsum [18]. For the late Holocene, the climate became drier, as indicated by intense shrinking of Tibetan lakes, as well as vegetation degradation (decreased pollen concentrations and increased relative percentages of dry species/genera) of the lake watersheds. Lake level decreases of as much as 10-20 m can be deduced from studies of the lake banks in both the northern and southern Plateau, which also resulted in disintegration of some large lakes, such as Lake Yangzhuoyongco, Chenco and Bajiuco in the southern Plateau, and the transition of exorheic lakes into inland lakes, such as Lake Yangzhuoyongco and Peikuco. With the exception of exorheic lakes in the eastern Plateau and some inland lakes that had just changed from exorheic lakes in the southern Plateau, most lakes of the Plateau were saline or brine lakes in the late Holocene. The saline lakes were primarily situated in the southern and northern parts of the Plateau, where the lake basin was subsequently enclosed, while the brine lakes were mainly distributed in the middle part of the Plateau and in the Qaidam Basin. Lakes such as Lake Zhacang Chaka had entered the last phase of the salt lake development during this period, and their sediment is mainly composed of mirabilite and halite. Overall, the late Holocene was an important period of salification for Tibetan lakes [18].

It should be pointed out that the highest stands of the Tibetan lakes appeared in the early Holocene rather than the megathermal period in the mid-Holocene. Tibetan lakes are typically characterized by discharges of glacial-melt water. In the early Holocene, the warm climate resulted in rapid glacial melting, which caused abrupt increases in lake levels. Comparatively, in the mid-Holocene, despite the higher air temperatures, the increased rainfall could not compensate for the decreased glacial-melt waters due to glacial with- 
drawals, and thus caused relatively lower lake levels in the late Holocene than in the early Holocene.

The sediment of the salt lakes north of the Tibetan Plateau also records lake environmental evolution and climatic changes in the lake area. It has been shown that, from the middle and late period of the late Pleistocene to the Holocene, the Tibetan Plateau rose to a considerable height, which screened the warm and humid air masses from the ocean to the south. This caused the development of interior dry land along a north-south route in the Plateau. At about $31 \mathrm{ka}$ BP, the western salt lake area in the Qaidam Basin was expanded to Lake Taijinaier. Lake Qarham then changed from a saline lake to a brine lake at about $25 \mathrm{ka} \mathrm{BP}$. Afterwards, Lake Da Qaidam in the northern Qaidam Basin changed into a self-depositing salt lake at about $19.5 \mathrm{ka} \mathrm{BP}$. From about $18.9 \mathrm{ka}$ BP, Lake Bangeco on the northern Tibetan Plateau changed to a brine lake. At about $11 \mathrm{ka} \mathrm{BP}$, Lake Zhacang Chaka became a self-depositing salt lake. Recently (several hundred years ago) some lakes in the southern Plateau underwent salification. After the interstadial of the last glacial period, many large lakes on the Tibetan Plateau disintegrated; therefore, the sediment is characterized by thick layers of carbonates (such as calcareous clay, calcite, aragonite, dolomite, magnesite, hydromagnesite, etc.) and borates (such as inderite, pinnoite, etc.) [18].

In the middle of the Holocene, Tibetan lakes underwent a short period of dilution, but this did not reverse the trend of lakes toward salt lakes (those on the northern Tibetan Plateau) or playas (Qarham lakes). In the late Holocene, salification was more widely observed for Tibetan lakes. Halite and mirabilite were the most common minerals deposited for these lakes, although many other carbonates, sulfates and borates (such as borax, tincalconite, pinnoite, etc.) were also deposited. The salification in the late Holocene (4 ka BP) has been revealed to be more widespread for Tibetan lakes than that in the late Pleistocene as indicated by many lakes having thick layers of pure mirabilite corresponding to the late Holocene. Specifically, layers of mirabilite $5 \mathrm{~m}, 4-6$ $\mathrm{m}, 3-4 \mathrm{~m}$ and $4 \mathrm{~m}$ thick were deposited in Lake Zhacang Chaka, Lake Bangeco, Lake Zhabuye Chaka, and Lake Mingyanco, respectively[19].

\subsection{Arid region lakes in Northwestern China}

Lakes in the arid regions of Northwestern China are mainly distributed in the Xinjiang and Mongolia Plateau (also known as the Mong-Xin Plateau). Most of these lakes are at the margin of the southeastern monsoon and those in northwestern Xinjiang are influenced by the westerly. According to changes in the water volume of palaeo-lakes since $30 \mathrm{ka} \mathrm{BP}$ (Figure 1) derived from the Chinese Lake Level Database [20], lake highstands at around $30 \mathrm{ka} \mathrm{BP}$ mainly occurred in western China. In this period, in contrast with the lakes in eastern China that had water shortages and very few lacustrine archives, the western China lakes were characterized by high water stands and diluted water. For example, a high lake level during 30-24 ka BP was revealed for Lake Balikun in Xinjiang, and Eucypris inflata and Leucocythere mirabilis appeared in the sediment during this period [21]. High lake stands were also found for Lake Baijian during 30-27 ka BP, when shells of Lamellibranchia were present in the sediment [9]. At $27 \mathrm{ka} \mathrm{BP}$, the western lakes were still characterized by high water stands and large water volumes, despite the increase of medium-sized lakes. However, at $21 \mathrm{ka} \mathrm{BP,} \mathrm{most} \mathrm{lakes} \mathrm{had} \mathrm{changed} \mathrm{from} \mathrm{large}$ lakes to medium sized lakes. For example, Lake Lopupo in Xinjiang was a middle-sized lake and the sediment from this period contained hydrophyte pollens and ostracod shells [22]. Even in the last glacial maximum, higher lake levels, larger lake surfaces and more diluted water were found in western lakes when compared to current conditions. This is significantly different from the situation for lakes in eastern China. Based on the international palaeo-climate modeling results [23,24], lakes in western China, central Asia and the Mediterranean occurred as a banded extension in the last glacial maximum. The high lake levels have been ascribed to the location change of the westerly. The intensified westerly and its southward shift gave rise to the convergence of cold and warm atmospheric currents and could have caused enhanced rainfall in western China during this period. Another reason for the high lake levels was the low air temperatures during the glacial period, which resulted in low evaporation and therefore less water loss from the lake reserves. This also caused a cold and humid climate for regions to the south of the westerly [25].

However, a dry climate was revealed by the loess archives in central Asia and monsoonal Asia during the last glacial period [26]. This was also a critical period for desert expansion in northern China [27]. The latest lacustrine archives (e.g. the record of Lake Bosten in Xinjiang[28]) show that modern lakes had not been formed during the last glacial period; accordingly, more chronology studies are required to determine if the humid climate in western China was present during the last glacial period.

During the late glacial period (15 ka BP), western lakes were mainly characterized by medium-sized lake surfaces. However, lakes (such as Lake Aibi, Chaiwobao, Wulun, etc.) in western Xinjiang (also discharged by glacial-melt water) attained high water stands as a result of increasing air temperatures [29]. Typical lacustrine facies dating back to 14.5 ka BP were also observed for Lop Lake [30]. Additionally, Lake Hulun in the eastern Mongolia Plateau attained a high water stand during the late glacial period, but this subsequently decreased at the YD event [31]. The earliest high water stands of Lake Daihai and Huangqihai (in central Mongolia) were found at about $10 \mathrm{ka}$ BP [32,33], but the lake levels were subsequently reduced in the late portion of the early Holocene. In the climatic optimum of the midHolocene, when the East Asian monsoon was intensified and expanding, the western lakes were under the multiple 


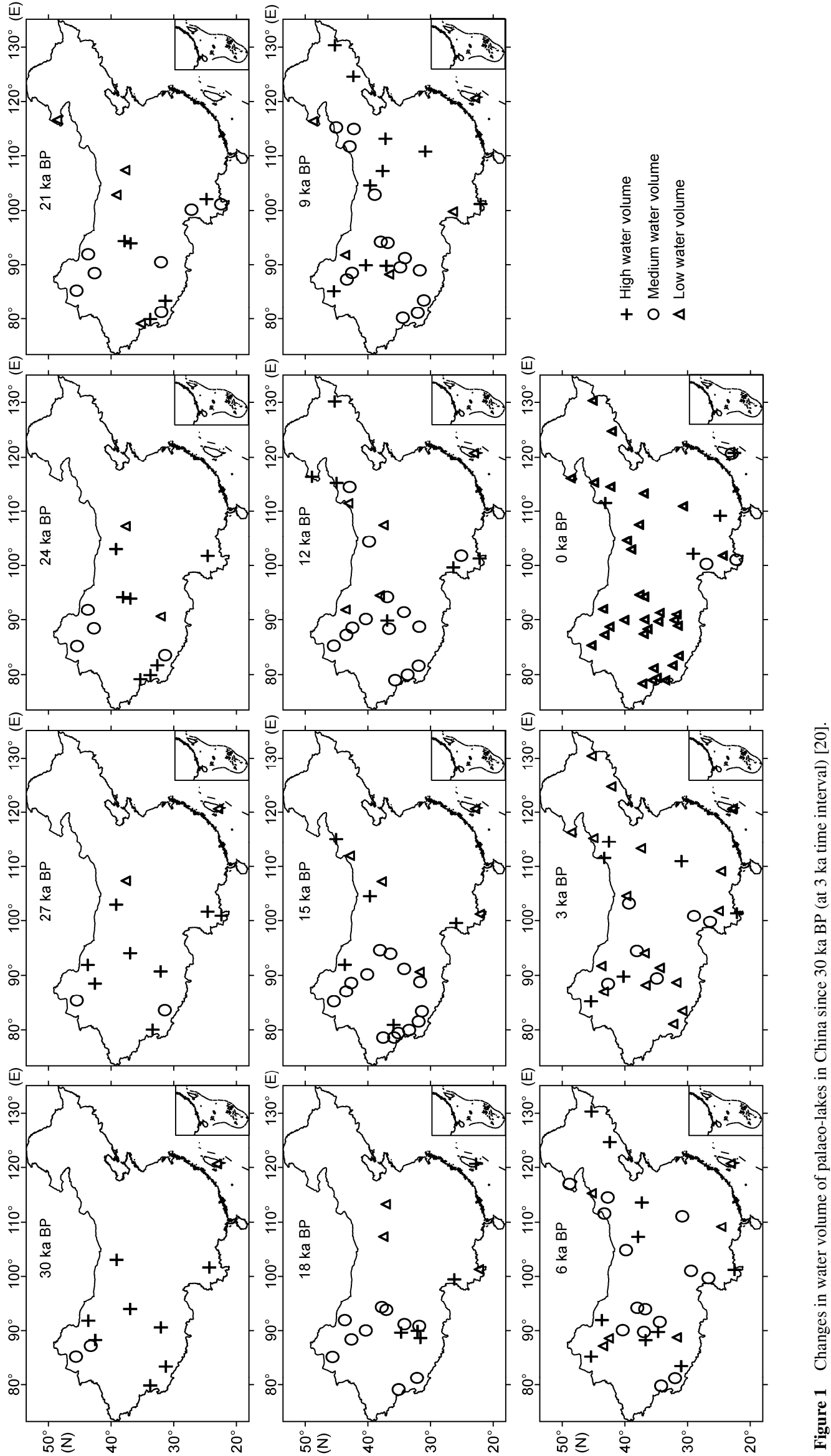


influences of the westerly and East Asian monsoon. It seems that for lakes in the eastern and southern areas, high water stands appeared earlier than for lakes in the northwestern part. For example, high lake levels of Lake Daihai and Huangqihai in Mongolia started and ended at 8 and $4 \mathrm{ka}$ $\mathrm{BP}$, respectively, while high stands of Lake Balikun and Wulun started and ended at 7 and $5 \mathrm{ka}$ BP, respectively. Following the thermal maximum, there was a general trend towards shrinking and salinization for the western lakes in the late Holocene despite the short reversal at $3 \mathrm{ka} \mathrm{BP}$, as observed for Lake Chaiwobao, Balikun, Aibi, Wulun in Xinjiang and Lake Hulun and Huangqihai in Mongolia.

According to the sediment records (pollen, isotopes, etc.) from arid regions in western China, the temperature variations have undergone three stages [34]: a temperature increase in the early Holocene (10 ka BP), peak temperature in the mid-Holocene, and a temperature decrease in the midand late-Holocene. For example, increased temperature and humidity and flourishing vegetation in the watershed were revealed for Lake Aibi (in northern Xinjiang) at $10.2 \mathrm{ka} \mathrm{BP}$, as indicated by the high values of TOC and organic $\delta^{13} \mathrm{C}$. Additionally, a warm and wet climate and high lake level were found at 7.3-6.3 ka BP, and the climate became warm and dry after $6.3 \mathrm{ka}$ BP [35]. Studies of Lake Wulun in the northeastern margin of northern Xinjiang revealed increases in lake water temperature (as evidenced by the ostracod assemblages normally present in warm and semi-salt waters) in the early Holocene [29], as well as lake expansion during 7.0-5.0 ka BP (as evidenced by the prairie-dominated vegetation of the catchment). For Lake Manas, water temperature increases and the formation of desert grassland in the catchment occurred immediately after $10.5 \mathrm{ka}$ BP [36,37] and the best condition in climate occurred during 9.0-6.5 ka BP. Temperature increases were also demonstrated by the records of oxygen and carbon isotopes from Lake Bosten, which indicate a thermal maximum during 7.0-5.0 ka BP [38] similar to that of Lake Wulun. Overall, dry climates were revealed for the periods of temperature increases in the early Holocene and temperature decreases after 5.0 ka BP, when the watersheds were dominated by desert or desert grassland, indicating westerly-dominant climates for Xinjiang. In contrast, increased rainfall and enhanced humidity during 7.0-5.0 ka BP (as reflected by the grassland-dominant watersheds) were revealed for Xinjiang, indicating the withdrawal of the westerly and the northwestward expansion of the East Asian monsoon. According to GCM modeling results for central and East Asia [39], the influences of the East Asian monsoon were extended to Xinjiang, which resulted in the thermal and humid maximum in the midHolocene, while in the late Holocene (after 3.0 ka BP), in addition to decreases in air temperature, the effective humidity declined as a result of the intensified westerly. This also caused very different climates in the late Holocene from that of the eastern monsoonal regions.

A recent synthesis study of climatic changes indicated that most humid climates of regions dominated by the westerly (including the inland arid zones in western China and dry regions on the northern Tibetan Plateau) were present during the middle and late Holocene, while most moist climates for the eastern monsoonal regions were present during the early and middle Holocene [40]. Modeling data indicate that the dry climates of central Asia in the early Holocene are not only related to the northward shift of the westerly in the mid-latitudes during winter and spring, but also to the reduced evaporation of the North Atlantic and a series of inland lakes (such as the Caspian Sea) in the upwind regions of the west [41]. In the past millennium, there was a dry climate in the medieval warm period (MWP) and a humid climate during the little ice age (LIA), which were reflected by the records of the westerly regions of China. Conversely, eastern monsoonal stalagmite records [42] show the opposite situations (e.g. increased rainfall in the MWP and decreased rainfall in the LIA) [43]. For the last century, especially during the last 50 years, the westerly regions have become increasingly humid, while the monsoonal regions (including northern China and the eastern part of northwestern China) have become drier [44]. In addition, an antiphase relationship has been found between the precipitation records from northern Tibet (westerly-dominant) and southern Tibet (monsoonal), not only on annual scales, but also on centennial scales. Based on these findings, Chen et al. [45] proposed a westerly-dominant climate model, which argued that the westerly-dominant climatic precipitation of the modern interglacial is different on every time scale (from millennial to annual scales) from that of the East Asian monsoon regimes.

The Mong-Xin Plateau is also one of the regions in which salt lakes exist. Most lakes in the Mongolia Plateau remained as fresh-water lakes during the early and middle Pleistocene until the late Pleistocene and early Holocene, when the lakes began deposition of carbonates as a result of intensified evaporation and salinization due to dry climates. For example, Lake Chahanuer in the Erlian Basin deposited carbonates such as natron and trona at $15 \mathrm{ka} \mathrm{BP}$. Nevertheless, salinization was limited to the regions of fault basins or depressed basins (such as Lake Jilantai and Lake Chahanuer in the Mongolia Plateau) [46,47]. In the thermal maximum of the mid-Holocene, layers of fresh-water deposition and chemical deposition (as a result of dry climates) appeared in the lake sediment, especially for the western and southwestern parts of the Mong-Xin Plateau. Since $6 \mathrm{ka} \mathrm{BP}$, Mongolian lakes have generally entered the phase of salification, resulting in the deposition of carbonates (pectolite, pirssonite, natron, thermonatrite, trona, etc.), sulfates (gypsum, mirabilite, thenardite, bloedite, etc.) and chlorides (halite, hydrohalite, etc.). The salification during the late Holocene was on a much larger scale and more widely observed in Inner Mongolia.

Comparatively few studies of salt lakes in Xinjiang have been conducted. A study of Lake Aibi showed that it un- 
derwent salinization after $24.9 \mathrm{ka} \mathrm{BP}$ and evolved to a brine lake after $10.9 \mathrm{ka} \mathrm{BP}$, which resulted in a pure mirabilite layer and halite crust [48].

\subsection{Humid region lakes in the Yunnan-Guizhou Plateau}

The Yunnan-Guizhou Plateau is predominantly influenced by the southwestern monsoon, which normally results in abundant rainfall. Therefore, monsoonal variations are the primary factor controlling environmental variations in the lakes. Most lakes in the Yunnan-Guizhou Plateau are tectonically derived fault lakes that were usually formed in the late Pliocene and the early Quaternary. For example, the 737 m continuous lacustrine archive from the Heqing Basin was found to span past 2.7 Ma [49]. Lake Dianchi came into being at about $3 \mathrm{Ma}$. Lake Lugu contains at least 18-m-thick sediment and the $12 \mathrm{~m}$ layer was dated back to $40 \mathrm{ka}$ BP. Additionally, the $12 \mathrm{~m}$ depth of the sediment from Lake Xingyun was older than $50 \mathrm{ka}$ BP. Taken together, these data indicate that lakes in the Yunnan-Guizhou Plateau have long histories.

Large lakes appeared in the Yunnan-Guizhou Plateau during 40-20 ka BP. During this period, the surface area of Lake Dianchi was three times greater than it is today, and Lake Fuxian and Xingyun were connected as a result of high lake levels. Additionally, the lake levels at the Heqing and Yuxi basins increased at that time. Lake Erhai was expanded considerably in every direction except east. During the last glacial maximum, a reduction in lake levels was observed as a result of weakened southwestern monsoon. Recent studies showed that there was a shift of the diatom assemblage from planktonic-dominating to benthic-dominating for Lake Lugu in the last glacial maximum, that water diminished in the palaeo-lake of Heqing and that the united large lake disintegrated.

Increasing lake levels were observed for the Yunnan-Guizhou lakes during the late glacial period, especially during the early Holocene, as a result of an intensified southwestern monsoon. However, owing to the obvious differences in lake altitudes, the timing and amplitude of lake levele variation differed from different regions. Whitmore et al. [50] and Hodell et al. [51] studied the sediment records of Lake Xingyun and Qilu and found enhanced lake productivity after $12000 \mathrm{cal} \mathrm{a} \mathrm{BP}$ and an intensified monsoon from 12000-8000 cal a BP. Increasing lake levels were found for Lake Erhai during the late glacial period, which resulted in the highest water stands being observed at $10300 \mathrm{cal}$ a BP [52]. For Lake Dianchi, the highest lake level was observed at $10 \mathrm{ka}$ BP [53]. Conversely, the records from Lake Shayema (Sichuan Province, China) indicate a relatively dry and cold climate during 11-9.1 ka $\mathrm{BP}$, with the highest lake level appearing after that time [54]. Pollen records [55,56] from the lakes of the YunnanGuizhou Plateau all indicate warm and humid climates in the early Holocene. The records from Lake Lunkaransar in India (also controlled by the southwestern monsoon) indicate that the highest lake levels occurred after 10.5 ka BP [57].

During the mid-Holocene, as the air temperature and precipitation increased, overall high lake levels were observed for the lakes in the Yunnan-Guizhou Plateau. These findings have been confirmed by the pollen records of these lakes. However, lake levels also decreased during the midHolocene due to the hot and dry westerly circulation and the rainfall differences among different altitudes. The so-called dry-hot-valley climate might also have contributed to this situation. Specifically, the valleys are currently usually characterized by increased air temperature and significant water loss via evaporation, which could have resulted in a very dry and hot regional climate and lowering of lake levels in these regions in the past [58]. Overall, the lake levels were generally high during the mid-Holocene, from 10-4 ka BP for Lake Lugu and Shayema, 6-4 ka BP for Lake Dianchi and 7.5-5.5 ka BP for Lake Erhai.

The pollen record indicates that after $4 \mathrm{ka}$ BP the southwestern monsoon withdrew and the climate began to dry [56]. The drying climate caused the reduction of lake levels until $2.7 \mathrm{ka} \mathrm{BP}$, as indicated by the sediment record (the accumulation of mulluscan shells) from Lake Erhai and the archaeological evidence from the lakeshores of Dianchi. However, the levels of Lake Shayema remained similar to the current levels after $4 \mathrm{ka} \mathrm{BP}$, while those of Lake Lunkaransar remained low from 3.5-2 ka BP. Nevertheless, during 2.7-1.7 ka BP, the lake level recovered and climate amelioration was observed for most lakes. Afterwards, aridification of the lakes resulted in a reduction in size in the Han Dynasty and levels ca. $3.0 \mathrm{~m}$ lower than the current levels in the middle Tang Dynasty.

\subsection{Plains region lakes in Eastern China}

The lakes in the plains of Eastern China are situated on the third-step ladder and are primarily influenced by the southeastern monsoon. In addition to the climatic influences, the lakes are also affected by changes in sea level and riverway migrations [59]. Moreover, the lakes have been intensely disturbed by human activities as the economy and population have grown.

In the last glacial maximum, the sea level was $130-150 \mathrm{~m}$ lower than today, resulting in strengthened down-cutting processes of the rivers. Moreover, most lakes in the region have opened and dried as a result of outflowing rivers, leading to production of fluvial facies as evidenced by the strata of Lake Taihu, Lake Boyang, Lake Dongting and Lake Baiyangding. The warming of climates in the early Holocene was accompanied by a rapid increase in sea levels, which flooded the foregoing lakes (such as those of the central western side of the Bohai Sea) along the coast. However, no large lakes existed in the middle and lower reaches of 
Yangtze River during this time, and only a few small lakes such as Lake Gucheng (Jiangsu Province) were present. Moreover, some places in northern China and eastern Mongolia had a few lakes (such as Lake Hulun and Daihai). Some of these developed peatbog depositions, such as $\mathrm{Pu}-$ landian $(9950 \pm 300$ a BP) in southern Liaoning Province, Gaolizhang $(9930 \pm 150$ a BP) in Beijing, Maojiahe (9535 \pm 170 a BP) in Changli, Hebei Province, and Nanpaihe $(10300 \pm 200$ a BP) in Huanghua, Hebei Province. In the mid-Holocene (7.5-3 ka BP), with the advent of the thermal maximum, the warm and wet climates caused lake expansion for the North China Plain in Eastern China. From southwest to northeast there are three depressional lake groups (Lake Daluze-Lake Ningjinpo, Lake BaiyangdingLake Wenanwa, Lake Qilihai-Lake Huangzhuangwa), which were probably connected to each other in the mid- Holocene and constituted a larger lake group. Large-scale lake groups in low depressions (such as Lake Yunmengze, Penglize, and other lake groups in the Jianghan Plain [60]) also occurred in the middle reaches of the Yangtze River as a result of rivers being overwhelmed due to increased rainfall as well as sea trangressions.

In the late Holocene (3-0 ka BP), the climate shifted toward dry and cold conditions. As a result, lakes in the Huabei Plain shrank and disintegrated, resulting in a series of unconnected small lakes, such as Lake Baiyangding in Heibei Province. However, lakes were widely distributed in the middle and lower reaches of the Yangtze River. In the lower reaches, sea level declines and the outreaches of the Yangtze River Delta caused the development of a series of freshwater lakes in the depressions, which were submerged by seawater. Hence, most lakes only occurred after the last transgression by sea and developed eastwards (seawards) as the sea retreated. Therefore, younger lakes are located more seaward. For example, Lake Taihu was formed around 2500 a BP [61]. Lake Xihu was also transformed by lagoons at about 2000 a BP, and Lake Sheyang (in the coastal plain of northern Jiangsu) was formed after 2000 a BP. Many lakes also formed in the middle reaches of the Yangtze River during the late Holocene. For example, Lake Boyang was formed at about $3 \mathrm{ka}$ BP (following the Han Dynasty) by the southwards flooding of the Ganjiang River, which was blocked by intrusion of the Yangtze River from the north [62]. Additionally, the palaeolake of Pengli disintegrated into small lakes such as Lake Longgan, Huangda, etc. Lake Dongting originally appeared during 2700-2200 a BP and was quickly enlarged since 1800 a BP[63].

During the historical periods, the evolution of lakes in eastern China was primarily influenced by climatic changes, with most lakes shrinking and becoming diminished during dry and cold periods (Wei-Jin and Northern-Southern Dynasties, Song Dynasty, and LIA subsequent to the 17th century) [64]. Another influencing factor is human activity, such as population migrations, soil erosion in response to land reclamation, lake siltation, and reduced lake surfaces following water reclamation [65]. It should be noted that the historical anthropogenic influences were usually superimposed on the natural trends in lake evolution controlled by climatic changes. For example, the peak historical reclamation coincided with lake retreats during the three cold periods mentioned above, while activities such as returning farmlands to lakes, river dredging, and construction of water-locks and dams usually occurred during warm climates associated with high lake levels. These findings show that climatic changes are the primary factors controlling the long-term evolutional trends in the plains lakes in eastern China.

Chronological errors can only partly account for the diverse spatio-temporal variations of lakes in the four regions reviewed above since the last glacial maximum. Nevertheless, other issues need to be emphasized. (1) Further investigations of the specific features of each lake, such as lake type, underwater topography, geographic location of different altitudes and landscapes, will enable a better understanding of the specific responses of lakes to climatic changes and help explain the miscorrelations between interlake records within the same region. (2) There are few lacustrine records spanning the last glacial maximum, and most archives for the Tibetan Plateau and western China are from palaeo-lake terraces; therefore, it is important to conduct further investigations of these regions during the period of lowered sea levels and intensified winter monsoon (weakened summer monsoon). (3) Records from humid eastern China and dry western China indicate asynchronization of the thermal maximum in the Holocene; however, further work is needed to clarify whether this was caused by the time-transgressive nature of monsoonal evolutions or the spatio-temporally different timing of sub-climatic systems. (4) The formation, expansion and diminishment of a lake are related to hydrological budgets of the watersheds. Therefore, in addition to paying attention to variations in water volume, investigation of water sources will facilitate our understanding of the large lakes period in the late lastinterstadial period, the high lake levels in the last glacial maximum, and the asynchronous appearances of high lake levels in the Holocene.

\section{Mechanisms driving lake evolution}

Lake evolution is mainly controlled by three factors, tectonic movements, climatic changes and human activities. Tectonic movements are primarily related to lake basin formation and long-term lake evolution, i.e. cycles of landform-sedimentation. Climatic forces driving lake evolution are ongoing and can be coupled with tectonic movements on $10^{6}-10^{4}$ a time scales as well as with human activities on $10^{2}-10^{1}$ a time-scales. Human activities are limited to historical periods, and can surpass the influences of natural factors in some cases. 
In China, the most impressive tectonic movement was the uplift of the Tibetan Plateau and the associated environmental effects, which not only had significant impacts on Tibetan lakes, but also exerted profound effects on monsoonal circulations, and therefore on other lakes near the Plateau. The climatic influences on lake evolution in China are characterized by the combined actions of the Asian monsoons and westerly. Currently, the growth and decline of the winter and summer monsoon has caused drying conditions associated with the development of closed salt lakes and brine lakes in western China, while climates in eastern and southern China are normally warm and wet, resulting in open and outflowing lakes. The Asian monsoon, as one of the important sub-systems of the global climate [66], is closely related to changes in insolation [67,68] and global ice volume [69-71] on $10^{4}$ a time scales. On $10^{4}-10^{3}$ a time scales, the lake evolution is not only affected by the land-atmosphere interactions of the high latitudes, but also by the ocean-atmosphere interactions of the low latitudes. The lake evolutions of China on various time scales are discussed below.

\section{1 $\quad 1^{6}$ a time scales}

Numerous studies of the uplifting of the Tibetan Plateau and its climatic and environmental effects have shown that uplifting processes can be divided into four stages: 22-20, 15-12, 8-7 and 3.4-2.5 Ma [72-74]. The intense uplift following $3.4 \mathrm{Ma}$ has been revealed in many lacustrine archives and is demonstrated by the massive gravel accumulations in basins around the Plateau, such as the gravel layers (3.4 Ma, marking the formation of the palaeolake) in the Linxia Basin, the Yumen gravel layers in the Hexi Corridor, and the Xiyu gravel layers (Tarim Basin) to the north of the western Kunlun Mountains. There is also other evidence of this, including the strata found in the Nihewan Basin, Sanmenxia and Yushe in northern China and the Kashmir Basin in southern Asia. Additionally, there are many fault basins in the Tibetan Plateau, as evidenced by gravel layers in the fault basin (subsided by tensional forces at 3.4 Ma) of the Kunlun Mountains. Other evidence includes the fluviallacustrine facies (3.4 Ma, of the Bulajia Formation) in the Dingri Basin and the lacustrine facies (2.8 Ma) in the Zoige Basin in the central portion of the Plateau. The tectonic movements (uplift) of the Tibetan Plateau during 3.4-2.5 Ma were the main reason for the lake formations [72,75] in the Plateau as well as in the Yunnan Plateau [76]. Subsequent to the uplift was a period of strengthened monsoon, which was associated with increased rainfall and deepening of lakes, such as Lake Zoige in Naqu of Tibet and the palaeo-lake of Heqing in Yunnan Province [49,77].

The most remarkable tectonic movements of the Quaternary were those in the middle Pleistocene, which resulted in abrupt changes in climates and environments. In the midPleistocene, the global climate changed as indicated by transformation of the $40 \mathrm{ka}$ glacial cycle into a $100 \mathrm{ka}$ glacial cycle. Moreover, the Tibetan Plateau was intensely uplifted during this period, fully reaching into the cryosphere and developing massive ice sheets on itself. For example, Lake Zoige (in the central Tibetan Plateau) was covered by ice and ceased sedimentation after $0.78 \mathrm{Ma}$ [77]. On the outskirts of the Plateau, basins were down-cut and the large pattern of Chinese rivers was formed during this time. Specifically, the Linxia Basin (in the high reaches of the Yellow River) was down-cut by the Yellow River, resulting in the highest terrain of the Lanzhou Basin [78]. Angular unconformity was also observed in the Upper-Sanmen and Lower-Sanmen formations in Pinglu of the Sannen Gorge [79]. Moreover, the "three gorges" were broken through and filled eastward during this period [80]. A few deep lake basins were also developed by uplift around the Plateau due to tensional forces, such as the Zoige Basin, which was formed around 0.9 Ma. Further evidence is provided by the Heqing Basin, which was deepened by tensional forces at about $0.9 \mathrm{Ma}$ as a result of the enlarged altitude difference between the lake basin and its surrounding mountains. This increase in altitude difference is demonstrated by the pollen record, which indicates the presence of more developed altitudinal belts and increased palynological diversity indices during this period [81]. The large patterns of Chinese rivers and landforms might have also come into being during the period.

\section{2 $\quad 10^{4}$ a time scales}

Orbital forcing is the main reason for global changes. The changes in orbital parameters (eccentricity, obliquity and precession) can cause varying insolation at different latitudes, which results in cyclical variations of the global climate. Records from deep-sea sediments and loess strata have revealed the cyclical variations and glacial-interglacial cycles of the global climate. The records from Lake Heqing indicate that orbital forcing can account for most changes in the palaeo-climate and palaeo-environment since $2.78 \mathrm{Ma}$ [76]. From 2.78 to $0.9 \mathrm{Ma}$, the climate was primarily affected by the low-latitude ocean, while after $0.9 \mathrm{Ma}$, uplifting of the Tibetan Plateau caused the global ice volumes to impact the climates via atmospheric circulation, as reflected by the cyclical transformation from 41 to $100 \mathrm{ka}$ [82].

For Lake Qinghai (Figure 2) the climates (on $10^{4}$ a time scales) began to be warm at $15.5 \mathrm{cal} \mathrm{ka} \mathrm{BP}$, reflecting the intensified East Asian monsoon. From 12.0 to $7.5 \mathrm{cal} \mathrm{ka} \mathrm{BP,}$ the humidity of the lake area was remarkably improved, as evidenced by the increased pollen concentrations, TOC and TN contents and decreased ostracod $\delta^{18} \mathrm{O}$. Specifically, two peaks (11.0 and 8.5 cal $\mathrm{ka} \mathrm{BP}$ ) are notable for the pollen concentrations, TOC and TN contents, while the ostracod $\delta^{18} \mathrm{O}$ was generally low from $11.5-7.5$ cal ka BP. Multiproxy results based on data synthesized after considering the proxies' different responses to the humidity and temper- 
ature of the lake area show that the best thermal-humid combination of Lake Qinghai should be at around 8.5 cal ka BP, reflecting the maximal intensification of the East Asian monsoon. Moreover, numerous geological archives and modeling results indicate the climax of the East Asian monsoon at about 9.0 cal ka BP [83]. Since 5.8 cal ka BP, the air temperature and humidity of the lake area have decreased as a result of weakening of the East Asian monsoon. Overall, since the last glacial maximum, the summer insolation of the northern hemisphere began to increase at about 15.0 cal ka BP, reached its maximum at about 10.0 cal ka BP and began to weaken at about 5.0 cal ka BP [84]. The records (pollen, TOC, TN and ostracod $\delta^{18} \mathrm{O}$ ) of Lake Qinghai resemble the general trend of insolation changes (Figure 2), indicating that on $10^{4}$ a time scales, the variations in the East Asian monsoon since the last glacial maximum were primarily driven by insolation changes in the northern hemisphere [85].

\subsection{Millennial scales}

Lake variations on millennial time scales are more complicated because of the regional characteristics of each lake, but overall they appear to be affected mainly by the regional effective precipitation (precipitation minus evaporation). The hydrological changes in Chinese lakes on millennial time scales have been described in detail in the Chinese
Lake Level Database of the Late Quaternary [20]. This database was established on the basis of studies of the sedimentary records of each lake (physico-chemical proxies, as well as pollen and other micro-fossil assemblages), topographic features for the lake basins and lake watersheds, and archeological and historical evidence. The database synthesized as many data as possible from all known sources of evidence to provide integrated data for palaeo-hydrology of Chinese lakes. Moreover, to be coupled with global lake databases, it also excludes the effects of non-climatic factors (such as flooding events, eruptive activities, tectonic activities, catchment erosion, human activities, etc.) and indirect climatic factors (such as glacial-melting waters, sea level variations, inter-catchment underground waters, etc.). Therefore, the database-yielded palaeo-hydrology can effectively reflect precipitation and net precipitation of the catchment. The database can also provide data for the spatially varying hydrology of Chinese lakes, which can be used to estimate and verify climatic modeling results. Based on the database, most Chinese lakes are currently (0 ka BP) at low levels due to water shortages. However, in the mid-Holocene (6 ka BP), the hydrological conditions of the lakes were spatially distinctively different. Moreover, in the last glacial maximum, lakes in west China showed high water levels, while those in eastern China had low levels. In the late interstadial period (30 ka BP), most western lakes remained at high lake levels, but few records exist for the

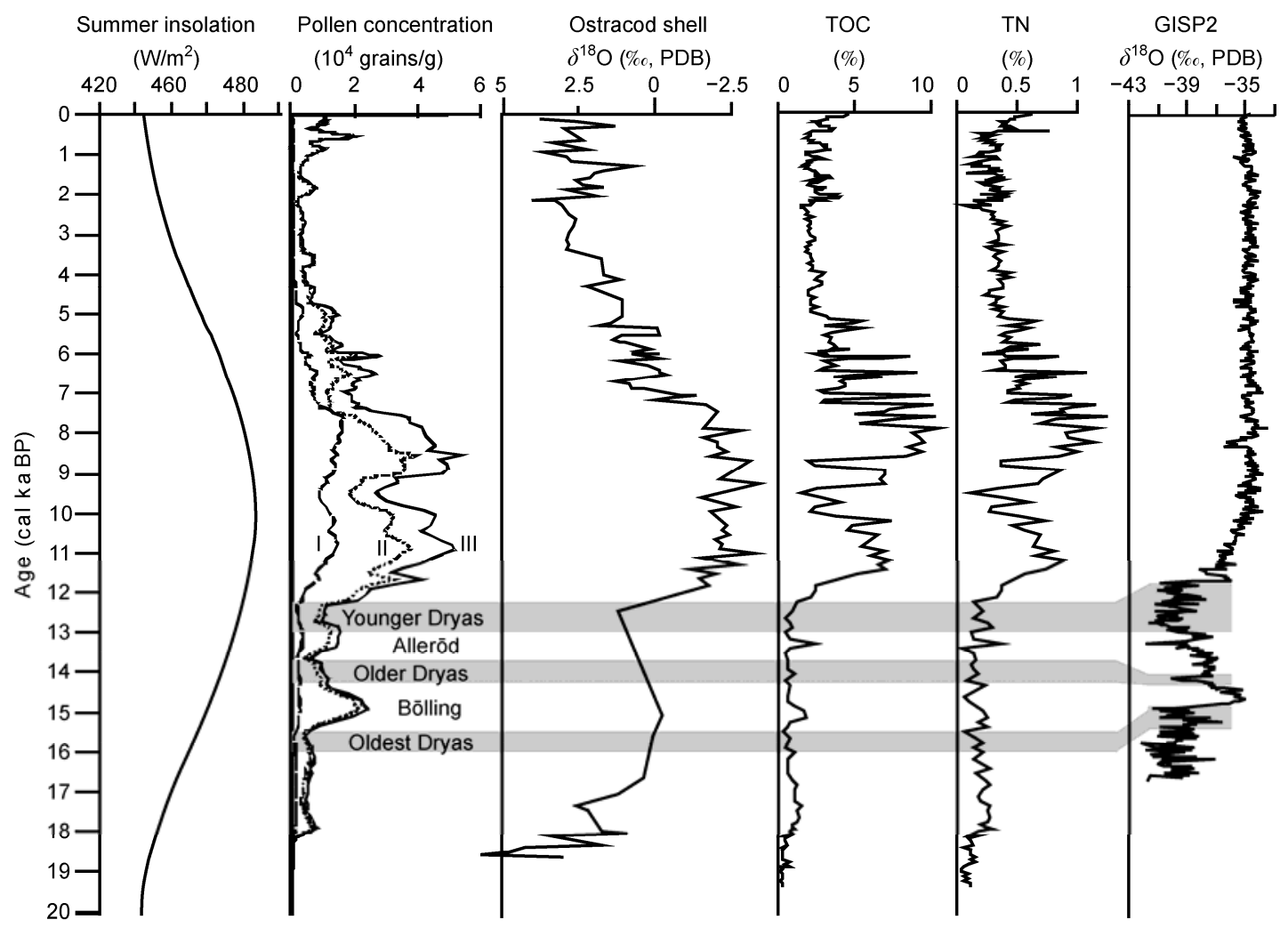

Figure 2 Multi-proxy records of Lake Qinghai [85]. I, Arboreal pollen; II, shrub and herbs pollen; III, total pollen. 
eastern lakes. Overall, these findings indicate that the interactions of the monsoon and westerly serve as the main driving-forces for general variations in lake hydrology [86].

Lake variations on millennial scales also have a close relationship with the instability of the climatic systems. Again taking Lake Qinghai as an example, the multi-proxy records are clearly impressed by the abrupt oscillating nature of the climate, which is well correlated with the rapid climatic changes observed in the GISP2 record (Figure 2). Such climatic instability has also been revealed by other records from different regions of China [87-89]. Taken together, these findings indicate that there are tele-connections of the East Asian monsoon with climates of the North Atlantic and changes in the ice-volume of the northern hemisphere on centennial scales. In addition, the climatic instability Lake Qinghai was subjected to is also indicated by a cold event at 8.2 cal ka BP [90] and cyclical (1.5 ka) variations [91,92]. Other records from China reveal similar instability of the Holocene climate [93]. For example, the cold event at 8.2 cal ka BP has been observed in different regions of China. Moreover, the $1.6 \mathrm{ka}$ cycle was shown to be present for variations in the Holocene summer monsoon based on the terminal lake sediment of the Shiyanghe Watershed, which is the marginal region of the monsoonal areas. Finally, this climatic stability can even been correlated with ice-rafting events in the North Atlantic [94].

\subsection{Centennial scales}

The recent variations in lacustrine environment (on centennial time scales) are closely related to anthropogenic factors. Lake sediment contains mixed information reflecting changes driven by both natural and anthropogenic factors. Hence, anthropogenic information extracted from lake sediment is important to resolution of the increasingly serious problems impacting ecological environments in lakecatchment systems. Moreover, past changes in human activities must be investigated to enable generation of standards for environmental restoration and remediation.

The ecological environment of Lake Erhai was significantly influenced by early human activities in the Holocene [95]. Specifically, it has been shown that human activities began at about $6370 \mathrm{cal}$ a BP, as evidenced by selected deforestation that caused degraded altitudinal belts of watershed vegetation and less-diverse palynological assemblages in the sediment (specifically, a shift from a Tsuga-Cyclob-
alanopsis-Quercus-Castanopsis-Pinus assemblage to a Pinus-predominated assemblage of secondary forests). Moreover, materials with coarse grain sizes and high carbonate contents were washed into Lake Erhai since that time. Since $2140 \mathrm{cal}$ a BP, as the population has increased, the forest coverage has become substantially reduced as a result of deforestation (as indicated by decreased pollen concentrations), while soil erosion of the watershed and the detrital materials that have washed into the lake both increased as a result of enhanced farming and mining (as indicated by the increased susceptibility and heavy metals ( $\mathrm{Pb}, \mathrm{Zn}$, etc.) concentrations in the sediment).

During the historical periods, human activities have exerted increasing effects on lakes in the middle and lower reaches of the Yangtze River, resulting in eutrophication of lakes in the region. Because of the lack of long-term monitoring data, it is difficult to know the exact natural background conditions that preceded eutrophication, the subsequent eutrophication processes and rates, or to estimate future eutrophic trends. Using the transfer function between diatom assemblage and total phosphorus (TP) of lake water, the TP concentrations for lakes in the middle and lower reaches of the Yangtze River were quantitatively reconstructed to estimate the natural background eutrophic conditions for different types of lakes (Table 1).

Coupled studies of lacustrine records and historical archives indicate that dry climates could influence concentrations of soluble nutrients and eutrophication, which can be effectively reduced or eliminated by floods. Moreover, restoration to the background levels preceding floods usually occurs rapidly following the discharge of floodwaters [97]. However, for the past 50 a, the continuously deteriorating eutrophication has been unprecedented, possibly due to the retention of water in response to increasing occurrences of blocked river systems (by man-made dams and water reclamation), as well as the reduced self-purification abilities of lakes as a result of prolonged residence times of nutrients. Indeed, a study of nutrient changes in Lake Longgan on centennial scales revealed that climatic changes serve as the main reason for changes in the nutrients before 1950, after which human activities played a key role, accounting for $60 \%$ and $57 \%$ of the total TP variations in sediment and in lake water, respectively [98].

Overall, lake sediment usually contains multiple sources of information reflecting the watershed, the lake, human activities and a mixture of these sources. Accordingly, this

Table 1 Historical variations in total phosphorus (TP) concentrations of lake water in the middle and lower reaches of the Yangtze River [96]

\begin{tabular}{lccc}
\hline & Lake Taihu & Lake Longgan & Lake Taibai \\
\hline Location & Jiangsu & Anhui-Hubei boundary & Huangmei, Hubei \\
Lake type & algae lake & macrophytic lake & algae lake \\
TP $(\mu \mathrm{g} / \mathrm{L})$ & $50-160$ & $40-68$ & $46-160$ \\
Period & past $200 \mathrm{a}$ & past 2000 a & past 500 a \\
\hline
\end{tabular}


causes difficulties when interpreting the sediment records and usually demands multi-proxy analysis. As an important archive for investigation of global change, lake sediment is influenced by different types of factors on global scales as well as regional and sub-regional scales. Moreover, the pattern and mechanism for lake variations has also changed on various time scales. Therefore, it is important to thoroughly understand the processes and mechanisms of lake evolutions. Accordingly, further studies to accomplish this are warranted.

\section{Prospects for further study}

We propose the following four aspects of work that should be investigated in the near future to enable a deep understanding of the spatio-temporal variations in Chinese lakes and their driving mechanisms $[99,100]$.

\subsection{Studies to enhance basic theoretical investigations conducted to interpret lake environment indicating proxies}

It is currently difficult to interpret the available lake environment indicating proxies because every specific proxy can be more or less influenced by a series of factors. Hence, it is important to investigate modern lake processes to precisely interpret these proxies. Therefore, further studies to investigate the quantitative relationship between proxies and the environment should be carried out to strengthen the quantitative reconstruction of the palaeo-environment. One method of accomplishing such studies is use of the related model of earth-surface pollen assemblages- functional vegetation-climatic parameters for a specific watershed, which can quantitatively deduce the climatic features based on the sediment pollen record. Laboratory culture of microbios can also improve our understanding by enabling transfer equations for water salinity by the trace element concentrations in microbios shells, which will facilitate quantitative deduction of water salinity changes in the past. Moreover, the $U_{\mathrm{k}}^{37}$ and $\mathrm{TEX}^{86}$ biomarkers can be used to reconstruct the palaeo-temperatures of lake water. Finally, the application of mathematical methods such as canonical correspondence analysis (CCA) can yield ordination of various environmental variables.

\subsection{Studies to identify new lake sediment records that are better resolved on both temporal and spatial scales}

Lake sediment is widely distributed around the world and normally continuously deposited, which both make it desirable for high-resolution studies of the evolution of various environments. To establish high-resolution time-series from environmental evolution, new technologies of chronology must be promoted in the near future to enlarge the ranges of available dating methods for lake sediment, especially for very old sediment that cannot currently be dated. Since the late 1980s, many lacustrine records of environmental changes have been produced. However, these records have different time resolutions and have involved different proxies, making it difficult to inter-record correlations and to understand inter-regional differences. Indeed, the records have been spatially and temporally limited to date, especially those spanning $100 \mathrm{ka}$ or more. For example, the lakes at high latitudes in Northern China are mutually influenced by the East Asian monsoon and polar ice sheets; therefore, the lake records can be used to deduce past changes in both monsoonal climates and polar ice sheets. The palaeo-lakes in the Sanmenxia Region provide another archive to record the formation of the loess plateaus and its environmental evolution; therefore, investigation of these lakes in Sanmenxia is important for understanding the origination of the East Asian monsoon, migrations of the Yellow River, frameworking of the three-step ladder landforms and cyclical oscillation between tectonic and climatic changes.

\subsection{Studies to emphasize anthropogenic effects on lake environments so artificial events can be deduced from lake sediment}

Recently deposited lake sediment encompasses mixed information pertaining to natural variations and human activities. In addition to historical documents, lake sediment provides anthropogenic information from periods before historical records were available. However, it is generally difficult to discriminate anthropogenic information in sediment from natural information. Therefore, it is important to quantitatively estimate the contribution of natural anthropogenic variations. Most of the available studies pertaining to environmental changes and human activities can only qualitatively estimate the intensities of human activities. Previous studies suggest that quantitative reconstruction of human activities and natural variations requires identifying effective anthropogenesis-indicating proxies (such as the indexes for population, farming area, etc.), climate-indicating factors (such as the indexes for temperature, precipitation, etc.) and lake-environment-indicating proxies (such as the indexes for physio-chemical and biological variables of lakes).

Currently, the most prominent issues for the lacustrine environments are eutrophication of lake water and combined contamination of lake sediment. The natural background conditions for the pre-eutrophication nutrients levels are vital to developing techniques for the elimination of eutrophication, which demands drawing information pertaining to pre-eutrophication background conditions as well as subsequent eutrophic variations in history, which can help make standards and targets for lake-environment restoration at different times. Moreover, information from 
sediment pertaining to the types of pollution and varying processes in the system can facilitate evaluation of changes in contaminating sources to provide correct guidelines against lake pollution.

\subsection{Studies to improve the Quaternary lake database of China for investigations of climatic dynamics}

The exact variations in precipitation and effective moisture can be revealed by investigation of lake level records deduced from palaeo-lake terraces, lake sediment and biostratigraphy. The international lake database was initially established in the late 1970s based on variations in lake levels in different locations. This worldwide database provides information regarding global changes (e.g. spatiotemporal variations in climates and atmospheric circulations in the Quaternary) and has become the test criterion for atmospheric circulation modeling results [101]. The construction of the Chinese Lake Level Database (CLLDB), which is based on numerous and widely-distributed lakes in China, has just begun. The CLLDB can help infer past changes in the East Asian monsoon and its spatial and temporal variations, which can be further used to test palaeoclimate modeling results. Moreover, coupled studies based on CLLDB data and modeling results can improve our understanding of specific atmospheric circulation patterns and the vapor transportation route.

The author thanks Prof. Wang Sumin for revising this manuscript. This work was supported by the National Natural Science Foundation of Distinguished Young Scholars of China (40625007), the National Basic Research Program of China (2012CB956100), and International Science \& Technology Cooperation Program of China (2011DFA21240).

1 Shen J, Xue B, Wu J L, et al. Lake Sediment and Environmental Evolution (in Chinese). Beijing: Science Press, 2010. 1-476

2 Wang S M, Dou H S. Chinese Lake Record (in Chinese). Beijing: Science Press, 1998. 1-580

3 Lehmkuhl F, Haselein F. Quaternary palaeoenvironmental change on the Tibetan Plateau and adjacent areas Western China and (Western Mongolia). Quatern Int, 2000, 65/66: 121-145

4 Li B Y. The last greatest lakes on the Xizang (Tibetan) Plateau (in Chinese). Acta Geogr Sin, 2000, 55: 174-182

5 Shi Y F, Yu G, Liu X D, et al. Reconstruction of the 30-40 ka BP enhanced Indian monsoon climate based on geological records from the Tibetan Plateau. Palaeogeogr Palaeoclimatol Palaeoecol, 2001, 169: 69-83

6 Li B Y, Zhang Q S, Wang F B. Evolution of the lakes in the Karakorum west-Kunlun Mountains (in Chinese). Quat Sci, 1991, 11: 64-71

7 Madsen D B, Ma H Z, Rhode D, et al. Age constraints on the late Quaternary evolution of Qinghai Lake, Tibetan Plateau. Quat Res, 2008, 69: 316-325

8 Long H, Lai Z, Fuchs M, et al. Late Quaternary palaeolake evolution in Tengger Desert of northern China: Timing and possible forcing mechanisms. Glob Planet Change, 2012, 92-93: 119-129

9 Pachur H J, Wünnemann B, Zhang H C. Lake evolution in the Tengger Desert, Northwestern China, during the last 40000 years. Quat Res, 1995, 44: 171-180

10 Zhang H C, Peng J L, Ma Y Z, et al. Late Quaternary palaeolake levels in Tengger Desert, NW China. Palaeogeogr Palaeoclimatol Palaeoecol, 2004, 211: 45-58
11 Yim W, Ivanovich M, Yu K. Young age bias of radiocarbon dates in pre-Holocene marine deposits of Hong Kong and implications for Pleistocene stratigraphy. Geo-Mar Lett, 1990, 10: 165-172

12 Bird M I, Ayliffe L K, Fifield L K, et al. Radiocarbon dating of "old" charcoal using a wet oxidation, stepped-combustion procedure. Radiocarbon, 1990, 41: 127-140

13 Briant R M, Bateman M D. Luminescence dating indicates radiocarbon age underestimation in late Pleistocene fluvial deposits from eastern England. J Quat Sci, 2009, 24: 916-927

14 Gu Z Y, Liu J Q, Yuan B Y, et al. Monsoon variation of the QinghaiXizang Plateau during the last 12000 years: Geochemical evidence from the sediments in Seling Lake. Chin Sci Bull, 1993, 38: 577-579

15 Li Y F, Zhang Q S, Li B Y. Ostracod fauna and environmental changes during the past 17000 years in western Tibet (in Chinese). Acta Geogr Sin, 1994, 49: 46-54

16 Gasse F, Arnold M, Fontes J C, et al. A 13000 year climate record from western Tibet. Nature, 1991, 353: 742-745

17 Van Campo E, Gasse F. Pollen and diatom inferred climatic and hydrological changes in Sumxi Co Basin (western Tibet) since $13000 \mathrm{yr}$ BP. Quat Res, 1993, 39: 300-313

18 Zheng M P, Xiang J, Wei X J, et al. The Salt Lakes in Qinghai-Tibet Plateau (in Chinese). Beijing: Beijing Science and Technology Publishing House, 1989

19 Zheng X Y, Tang Y, Xu Y, et al. Salt Lakes of Tibet (in Chinese). Beijing: Science Press, 1988

20 Xue B, Yu G, Wang S M. Lake water variations in China since 30000 a BP. Quat Res, 2001, 21: 567

21 Han S T, Wu N Q, Li Z Z. Environmental change of inland-type climate during the late period of late-Pleistocene in northern Xinjiang (in Chinese). Geogr Res, 1993, 12: 47-54

22 Yan S, Mu G J, Xu Y Q, et al. Quaternary environmental evolution of the Lop Nur region, China (in Chinese). Acta Geogr Sin, 1998, 53: 332-340

23 COHMAP Members. Climatic changes of the last 18000 years: Observations and model simulations. Science, 1988, 241: 1043-1052

24 Fang J Q. Lake evolution during the past 30,000 years in China and its implication for environmental changes. Quat Res, 1991, 36: 37-60

25 Yu G, Xue B, Wang S M, et al. Lake-level records and the LGM climate in China. Chin Sci Bull, 2000, 45: 250-255

26 Ding Z L, Ranov V, Yang S L, et al. The loess record in southern Tajikistan and correlation with Chinese loess. Earth Planet Sci Lett, 2002, 200: 387-400

27 Sun J M, Ding Z L, Liu T. Desert distributions during the glacial maximum and climatic optimum: Example of China. Episodes, 1998, 21: 28-30

28 Huang X Z, Chen F H, Fan Y X, et al. Dry late-glacial and early Holocene climate in arid central Asia indicated by lithological and palynological evidence from Bosten Lake, China. Quat Int, 2009, 194: 19-27

29 Yang X D, Wang S M. Pollen assemblage and environmental changes in the last 12000 years in Wulungu Lake (in Chinese). Arid Zone Res, 1994, 11: 7-10

$30 \mathrm{Wu}$ Y S. The sporo-pollen assemblage and its significance of pit F4 from Lop Nur area in Xinjiang (in Chinese). Arid Land Geogr, 1994, 17: 24-28

31 Wang S M, Ji L, Yang X D, et al. The Research About Ancient Lake: The Case of Hulun Lake (in Chinese). Hefei: University of Science and Technology of China Press, 1995

32 Wang S M, Wu R J, Jiang X H. Environment evolution and paleoclimate of Daihai lake, Inner Mongolia since the last glaciations (in Chinese). Quat Sci, 1990, 90: 223-232

33 Li H Z, Liu Q S, Wang J X. Study of evolution of Huangqihai and Daihai lakes in Holocene in Inner Mongolia Plateau (in Chinese). J Lake Sci, 1992, 4: 31-39

34 Zhou J, Shen J. Eco-environment Evolution in West China (in Chinese). Beijing: Science Press, 2007

35 Wu J L, Shen J, Wang S M, et al. Characteristics of an Early Holocene climate and environment from lake sediments in Aibi region, NW China. Sci China Ser D: Earth Sci, 2005, 48: 258-265 
36 Sun X J, Du N Q, Weng C Y, et al. Paleovegetation and paleoenviroment of Manasi Lake, Xinjiang, N. W. China during the last 14000 years (in Chinese). Quat Sci, 1994, 14: 239-248

37 Lin R F, Wei K Q, Cheng Z Y, et al. A palaeoclimatic study on lacustrine cores from Manas Lake, Xinjiang, western China (in Chinese). Geochimica, 1996, 25: 63-72

38 Zhong W, Xiong H G. Preliminary study on paleoclimatic evolution since about $12 \mathrm{ka}$ BP in Bosten Lake, southern Xinjiang, China (in Chinese). J Arid Land Resour Environ, 1998, 12: 29-35

39 Qin B Q, Shi Y F, Yu G. The reconstruction and interpretations of lake status at $6 \mathrm{ka}$ and $18 \mathrm{ka} \mathrm{BP}$ in inland Asia. Chin Sci Bull, 1998, 43: 1145-1157

40 Chen F H, Yu Z C, Yang M L, et al. Holocene moisture evolution in arid central Asia and its out-of-phase relationship with Asian monsoon history. Quat Sci Rev, 2008, 27: 351-364

41 Jin L Y, Chen F H, Morrill C, et al. Causes of early Holocene desertification in arid central Asia. Clim Dyn, 2011, doi: 10.1007/s00382011-1086-1

42 Zhang P, Cheng H, Edward s R L, et al. A test of climates and culture relationships from an 1810-year Chinese cave record. Science, 2008, 322: 940-942

43 Chen F H, Chen J H, Holmes J, et al. Moisture changes over the last millennium in arid central Asia: A review, synthesis and comparison with monsoon region. Quat Sci Rev, 2010, 29: 1055-1068

44 Chen $\mathrm{F} \mathrm{H}$, Chen J H, Huang W. A discussion on the westerlydominated climate model in mid-latitude Asia during the modern interglacial period (in Chinese). Earth Sci Front, 2009, 16: 23-32

45 Chen F H, Huang W, Jin L Y, et al. Spatiotemporal precipitation variations in the arid Central Asia in the context of global warming (in Chinese). Sci China Earth Sci, 2011, 54: 1812-1821

46 Zheng X Y, Zhang M G, Dong J H, et al. Salt Lakes of Inner Mongolia (in Chinese). Beijing: Science Press, 1992

47 Li R Q. The Lake Evolution and Environmental Changes of the Inner Mongolia Plateau (in Chinese). Beijing: Beijing Normal University Press, 1992

48 Li B X, Cai B Q, Liang Q S. Sedimentary feature of Aiding Lake in Tulufan Basin (in Chinese). Chin Sci Bull, 1989, 34: 608-610

49 Shen J, Wang S M, Wang Y, et al. Uplift events of the QinghaiTibetan Plateau and environmental evolution of the southwest monsoon since $2.7 \mathrm{Ma}$, recorded in a long lake sediment core from Heqing, China. Quat Int, 2010, 218: 67-73

50 Whitmore T J, Brenner M, Song X L. Environmental implications of the late Quaternary diatom history from Xingyun $\mathrm{Hu}$, Yunnan Province, China. In: Kociolek J P, ed. Proceedings of the 11th International Diatom Symposium. Memoirs of the California Academy of Sciences, 1994, 17: 525-538

51 Hodell D, Brenner M, Kanfoush S L, et al. Paleoclimate of southwestern China for the past $50000 \mathrm{yr}$ inferred from lake sediment records. Quat Res, 1999, 52: 369-380

52 Shen J, Yang L Y, Yang X D, et al. Lake sediment record on change and human activities since the Holocene in Erhai catchment of Yunnan Province, China. Sci China Ser D-Earth Sci, 2005, 48: 353-364

53 Wu R J, Xiang L, Qian J L. Sedimentary records of recent environmental deterioration in Dianchi Lake (in Chinese). In: Bulletin of Nanjing Institute of Geography and Limnology, Chinese Academy of Sciences. Beijing: Science Press, 1995. 1-10

54 Jarvis D I. Pollen evidence of changing Holocene monsoon climate in Sichuan Province, China. Quat Res, 1993, 39: 325-337

55 Walker D. Late Pleistocene-early Holocene vegetational and climatic changes in Yunnan Province, southwest China. J Biogeogr, 1986, 13: $477-486$

56 Sun X J, Wu Y S. Holocene vegetation history and environmental changes of the Dianchi lake area, Yunnan Province (in Chinese). In: Article Collection of China-Australia Quaternary Symposium. Beijing: Science Press, 1987. 28-41

57 Swain A M, Kutzbach J E, Hastenrath S. Estimates of Holocene precipitation for Rajasthan, India, based on pollen and lake-level data. Quat Res, 1983, 19: 1-17

58 Editorial Committee of Yunnan Vegetation. Vegetation of Yunnan.
Beijing: Science Press. 1987. 417, 771-773

59 Huang D F. Geological studies of the formation and development of the three large freshwater lakes in the lower Yangtze valley (in Chinese). Oceanol Limnol Sin, 1965, 7: 396-426

60 Editing Committee of "Geography in China". Chinese Academy of Sciences ed. Geography in China: Historical and Natural Geography. Beijing: Science Press, 1982. 123-130

61 Sun S C, Huang Y P. Taihu Lake (in Chinese). Beijing: Ocean Press, 1993. 1-271

62 Su S D. Historical documents on the origin and evolution of Poyang Lake (in Chinese). J Lake Sci, 1992, 4: 40-47

63 Dou H S, Jiang J H. Dongting Lake (in Chinese). Hefei: Chinese Science and Technology University Press, 2000. 1-340

64 Dou H S, Jiang J H. First Five Biggest Lakes in China (in Chinese). Hefei: University of Science and Technology of China Press, 2003. 1-299

65 Jing C Y. Formation and evolution of Hongze Lake (in Chinese). J Hohai Univ, 1987, 15

66 An Z S, Liu X D. The history and variability of East Asian Monsoon (in Chinese). Chin Sci Bull, 2000, 45: 238-249

67 An Z S, Porter S C. Magnetic susceptibility evidence of monsoon variation on the Loess Plateau during the past $130 \mathrm{ka}$ (in Chinese). Chin Sci Bull,1990, 35: 529-532

68 Guo Z T, Liu T S, An Z S. Paleosols of the last 0.15 Ma in the Weinan loess section and their paleoclimatic significance (in Chinese). Quat Sci, 1994, 14: 256-269

69 Liu T S, Ding Z L. Stepwise coup ling of monsoon circulation to continental ice-volume variations during the past 2500000 years (in Chinese). Quat Sci, 1992, 12: 12-23

70 Ding Z, Liu T, Rutter N, et al. Ice-volume forcing of East Asian winter monsoon variations in the past 800000 years. Quat Res, 1995, 44: 149-159

71 Ding Z L, Yu Z W. Forcing Mechanisms of paleomonsoons over East Asia (in Chinese). Quat Sci, 1995, 1: 63-74

72 Li J J, Fang X M. Uplift of the Tibetan Plateau and environmental changes. Chin Sci Bull, 1999, 44: 2117-2174

73 An Z S, Zhang P Z, Wang E Q, et al. Changes of the monsoon-arid environment in China and growth of the Tibetan Plateau since the Miocene (in Chinese). Quat Sci, 2006, 26: 678-693

74 Liu X D, Li L, An Z S. Tibetan plateau uplift and drying in Eurasian interior and northern Africa (in Chinese). Quat Sci, 2001, 21: 114-122

75 Shi Y F, Li J J, Li B Y. Uplift and Environmental Changes of Qinghai-Xizang (Tibetan) Plateau in the Late Cenozoic (in Chinese). Guangzhou: Guangdong Science and Technology Press, 1998. 1-463

76 Shen J, Xiao H F, Wang S M, et al. The orbital scale evolution of regional climate recorded in a long sediment core from Heqing, China. Chin Sci Bull, 2007, 52: 1813-1819

77 Shen J, Lu H Y, Wang S M, et al. A 2.8 Ma record of environmental evolution and tectonic events inferred from the Cuoe core in the middle of Tibetan Plateau. Sci China Ser D-Earth Sci, 2004, 47: 10251034

78 Pan B T, Su H, Hu C S, et al. Discovery of a 1.0Ma Yellow River terrace and redating of the fourth Yellow River terrace in Lanzhou area (in Chinese). Prog Nat Sci, 2006, 16: 1411-1418

79 Wang S M, Wu X H, Zhang Z K, et al. Sedimentary recods of environmental evolution in the Sanmen Lake Basin and the Yellow River running through the Sammenxia Gorge eastward into the sea. Sci China Ser D-Earth Sci, 2002, 45: 595-608

80 Li J, Xie S, Kuang M. Geomorphic evolution of the Yangtze Gorges and the time of their formation. Geomorphology, 2001, 41: 125-135

81 Xiao X Y, Shen J, Wang S M, et al. Palynological evidence for vegetational and climatic changes from the HQ deep drilling core in Yunnan Province, China. Sci China Ser D-Earth Sci, 2007, 50: 11891201

82 An Z S, Clemens S C, Shen J, et al. Glacial-Interglacial India Summer Monsoon Dynamics. Science, 2011, 333: 719-723

83 An Z S. The history and variability of the East Asian paleomonsoon climate. Quat Sci Rev, 2000, 19: 171-187

84 Berger A, Loutre M. Insolation values for the climate of the last 10 
million years. Quat Sci Rev, 1991, 10: 297-317

85 Shen J, Liu X Q, Wang S M, et al. Palaeoclimatic changes in the Qinghai Lake area during the last 18000 years. Quart Int, 2005, 136: 131-140

86 Xue B, Yu G. The Lake status changes of China since LGM and its significance for Palaeoclimate (in Chinese). J Lake Sci, 2005, 17: $35-40$

87 Yao T D, Thompson L G, Shi Y F, et al. A study of climatic variations since last interglaciation in the Guliya ice core (in Chinese). Sci China Ser D: Earth Sci,1997, 27: 447-452

88 Wang W Y, Liu J Q, Liu T S, et al. The two-step monsoon changes of the last deglaciation recorded in tropical Maar Lake Huguangyan, Southern China (in Chinese). Chin Sci Bull, 2000, 45: 860-864

89 Wang Y Q, Yao T D. Progresses in the studies of abrupt climatic change events recorded in ice cores during the last glacial- interglacial cycle (in Chinese). J Glaciol Geocryol, 2002, 24: 550-558

90 Alley R, Mayewski P, Sowers T, et al. Holocene climatic instability: A prominent, widespread event $8200 \mathrm{yr}$ ago. Geology, 1997, 25: 483-486

91 O'brien S, Mayewski P, Meeker L, et al. Complexity of Holocene climate as reconstructed from a Greenland ice core. Science, 1995, 270: 1962-1964

92 Campbell I, Campbell C, Apps M, et al. Late Holocene approximately $1500 \mathrm{yr}$ climatic periodicities and their implications. Geology, 1998, 26: 471-473

93 Shi Y F, Kong Z C. Paleoclimatic fluctuations and important events during the Holocene Megathemal in China (in Chinese). Sci China Ser D: Earth Sci, 1992, 22: 1300-1308
94 Chen F H, Zhu Y, Li J J, et al. Abrupt Holocene changes of the Asian monsoon at millennial- and centennial-scales: Evidence from lake sediment document in Minqin Basin, NW China (in Chinese). Chin Sci Bull, 2001, 46: 1414-1419

95 Shen J, Jones R, Yang X, et al. The Holocene vegetation history of Lake Erhai, Yunnan province southwestern China: The role of climate and human forcings. Holocene, 2006, 16: 265-276

96 Yang X D, Shen J, Dong X H, et al. Historical trophic evolutions and their ecological responses from shallow lakes in the middle and lower reaches of the Yangtze River: Case studies on Longgan Lake and Taibai Lake (in Chinese). Sci China Ser D: Earth Sci, 2005, 35(Suppl.2): 45-54

97 Liu E F, Yang X D, Shen J, et al. Environmental response to climate and human impact during the last 400 years in Taibai Lake catchment, middle reach of Yangtze River, China. Sci Total Environ, 2007, 385: 196-207

98 Yang X D, Anderson N, Dong X H, et al. Surface sediment diatom assemblages and epilimnetic total phosphorus in large, shallow lakes of the Yangtze floodplain: Their relationships and implications for assessing long-term eutrophication. Freshwater Biol, 2008, 53: 12731290

99 Wang S M, Zhang Z K. The new progress of the study about lake sediment and environmental evolution in China (in Chinese). Chin Sci Bull, 1999, 44: 579-587

100 Shen J. Progress and prospect of palaeolimnology research in China (in Chinese). J Lake Sci, 2009, 21: 307-313

101 Yu G. Studies on global late Quaternary lake-level data base (in Chinese). J Lake Sci, 1997, 9: 193-202

Open Access This article is distributed under the terms of the Creative Commons Attribution License which permits any use, distribution, and reproduction in any medium, provided the original author(s) and source are credited. 